\title{
VALE QUANTO PESA: o que leva(m) mulheres grávidas à prisão? // Heloisa Vieira Simões ${ }^{1}$, Priscilla Conti Bartolomeu ${ }^{2}$ e Priscilla Placha Sá ${ }^{3}$
}

"O comando compra mulheres grávidas por 600,00, faz isso até na entrada do sistema." (fala de uma entrevistada)

\section{Palavras chave}

corpo / drogas / encarceramento feminino / prisão

HIIIIIIIIIIIIIIIIIIIIIIIIIIIIIIIIII

\section{Sumário}

\section{Introdução}

2 Recorte da pesquisa: mulheres privadas de liberdade e mulheres que visitam pessoas privadas de liberdade

2.1 Epistemologia feminista

2.2 Local da realização da pesquisa

2.2.1 Com as mulheres privadas de liberdade grávidas e com as mulheres que estão com crianças

2.2.2 Com as mulheres que visitam pessoas privadas de liberdade

2.3 Da pesquisa com as mulheres privadas de liberdade gestante e com crianças

2.4 Da Pesquisa com as mulheres que visitam pessoas privadas de liberdade

3 Sistematização dos dados colhidos

3.1 Da coleta de dados obtidos com as mulheres privadas de liberdade

3.2 Sistematização dos dados das mulheres que visitam pessoas privadas de liberdade

4 Discussão e análise da intersecção dos dados colhidos

5 Possíveis conclusões

6 Referências

\section{Resumo}

O exponencial crescimento do número de mulheres encarceradas no Brasil não mudou o contexto de invisibilidade em que vivem. Diante de tal silêncio, e tendo a percepção de que é em face do feminino e de seu corpo que o sistema de justiça criminal parece expressar sua mais perversa atuação, o Projeto Mulheres pelas Mulheres se propôs a dar voz e visibilidade a essas mulheres. A partir de uma série de entrevistas - com as próprias internas e com as mulheres que visitavam presos nas penitenciárias de Piraquara-PR - foi possível traçar um perfil da mulher encarcerada no Paraná. Entretanto, chamou a atenção a expressiva quantidade de mulheres grávidas e com bebês dentro do sistema. Assim, tendo como base uma epistemologia feminista, foi possível perceber, através dos relatos e de informações a respeito da visita, da revista e das circunstâncias da prisão de determinadas mulheres, um padrão, uma série de histórias

1 Mestranda em Direito do Estado pela UFPR. Graduada em Direito pela Faculdade de Direito da UFPR. Membro do Projeto "Mulheres pelas Mulheres”. Membro do Grupo de Pesquisas “Antígona”. Membro do Núcleo de Pesquisa em Criminologia e Política Criminal da UFPR. Voluntária do Projeto de Extensão “Igualdade e Gênero”: enfrentando a violência contra a Mulher da UFPR. Advogada.

2 Graduanda em Direito pela Faculdade de Direito da UFPR. Membro do Projeto "Mulheres pelas Mulheres". Membro do Grupo de Pesquisas “Antígona”. Membro do Núcleo de Pesquisa em Criminologia e Política Criminal da UFPR. Bolsista do Projeto de Extensão "Igualdade e Gênero": enfrentando a violência contra a Mulher da UFPR.

3 Doutora em Direito do Estado pela UFPR. Professora Adjunta de Direito Penal da Graduação na PUCPR e na UFPR. Professora do Programa de Mestrado em Direitos Humanos e Políticas Públicas da PUCPR. Vice-Chefe de Departamento de Direito Penal e Processual Penal da UFPR. Coordenadora do Projeto de Extensão "Mulheres pelas Mulheres". Coordenadora do Grupo de Pesquisa "Antígona”, parceria da UFPR e da PUCPR. Vice-Coordenadora do Núcleo de Pesquisa em Criminologia e Política Criminal da UFPR. Membro do Grupo de Pesquisas Modernas Tendências do Sistema Criminal, da FAE. Advogada Criminal. Presidente da Comissão de Defesa de Prerrogativas Profissionais da OAB/PR. Consultora da Comissão de Estudos de Violência de Gênero da OAB/PR. Membro do Comitê Estadual de Políticas Públicas para Mulheres Privadas de Liberdade do DEPEN-PR. 
repetidas. Mulheres grávidas que, nas filas para a visita, recebem ofertas razoáveis de dinheiro em troca de um serviço, cujo sucesso já estaria acertado com os responsáveis pela revista. Em um instante, porém, tornam-se, para o sistema de justiça criminal, traficantes. Mulheres-traficantes que trazem no ventre a paradoxal contradição de serem mulheres-traficantes-grávidas, subvertendo a ordem de gênero e os papeis naturalmente estabelecidos, caracterizando aquilo que, simbolicamente, não se admite: que uma criminosa seja, também, mãe. 


\section{WORTH HOW MUCH IT WEIGHTS: what leads pregnant women to prison? // Heloisa Vieira Simões, Priscilla Conti Bartolomeu and Priscilla Placha Sá}

"The command purchase pregnant women for $R S$ 600,00 , they do this even at the system's entrance." (speech of an interviewed)

\section{Keywords}

body / drugs / female incarceration / prison

\section{Abstract}

The exponential growth in the number of incarcerated women in Brazil did not change the invisibility context in which they live. Faced with this silence, and realizing that is against the feminine and their body that the criminal justice system seems to express its most perverse acting, the project Mulheres pelas Mulheres aimed to give voice and visibility to those women. From a series of interviews - with the imprisoned women and with the women visiting prisoners at the penitentiaries of Piraquara-PR - it was possible to draw a profile of the incarcerated women in Paraná. However, it was surprising the significant number of pregnant women and with babies within the system. Thus, based on a feminist epistemology, it was possible to notice, by the narratives and the information about the visit, the visitor's inspection and the prison circumstances of certain women, a pattern, a series of repeated stories. Pregnant women that, in the visitors' queues, receive substantial offers of money in exchange for a service, which success would have already been agreed with the in charge of the inspection. Suddenly, however, they become, for the criminal justice system, drug dealers. Women-drug-dealers who bring in their womb the paradoxical contradiction of being women-pregnant-drug dealer, subverting the gender order and the naturally established roles, representing what, symbolically, it is not allowed to admit: that a criminal could be, also, a mother. 


\section{Introdução}

0 estudo relacionado à mulher considerada criminosa (Perrot, 1988), bem como às complexas causas que leva mulheres ao cárcere e o que leva ao cárcere e às condições em que se encontra privada de liberdade, é fenômeno relativamente recente (Cortina, 2015). A partir das formulações de Vera Andrade, é possível inferir que esse silêncio a respeito das relações entre a mulher e o sistema de justiça criminal é decorrente da própria estrutura patriarcal da sociedade, e da naturalização dos papeis historicamente atribuídos a homens e mulheres. Em um contexto social que tem como base a dicotomia entre o "cara" e a "coisa", é compreensível esse caráter masculino do cárcere e do sistema penal (Andrade, 2012, pp. 142-144).

Dotado do poder patriarcal na esfera privada, o homem ativo-improdutivo deveria ser controlado pelo poder punitivo na esfera pública - elemento essencial a uma sociedade capitalista - o qual seria exercido em face de todos aqueles que não se adéquam aos modelos de produção (Andrade, 2012, p. 142-144). Já a mulher desviante seria alvo de um poder de controle específico, exercido principalmente no âmbito doméstico e familiar, que tomaria a forma de custódia, impondo-lhes os mais diversos tipos de penas, desde privação de liberdade (em casa, nos conventos ou até mesmo em manicômios) até restrições alimentares e limitações de gestualidade e de liberdade de fala (Mendes, 2014, pp. 115-118). Sobretudo, um controle sobre os seus corpos, como último gabarito de inteligibilidade das diferenças (Heretiér, 2015) e sua sexualidade (Hespanha, 2010).

Entretanto,ocrescimento exponencialdonúmerodemuIheresprivadasdesualiberdadenoBrasilnosúltimosanos ${ }^{5}$

4 Os termos "cara" e "coisa" referem-se às ideias de Vera Regina Pereira de Andrade (2012), que afirma que na ordem patriarcal de gênero o homem é referido como o cara - aquele que faz, o ativo, o ator exaltado e temido dos grandes feitos - e a mulher é a coisa, o contraponto do cara, é o passivo, aquilo que sofre as ações no curso da história.

5 Dados do Departamento Penitenciário Nacional (Brasil, 2015a) apontam que em 2000 haviam cerca de 05 mil mulheres nas penitenciárias brasileiras; em 2014, esse número saltou para 37.380 , representando um aumento de $567 \%$. No mesmo período, a população carcerária masculina - embora expressivamente maior em números absolutos - apresentou um crescimento bem menor, de “apenas" 220\%. ganhou lugar nas pesquisas - inclusive, oficiais - rompendo com esse apagamento, dando ênfase a pesquisas criminológicas que buscassem compreender tal fenômeno, a partir de categorias e questões próprias dos estudos de caráter feminista.

E é justamente nesse contexto que o Projeto Mulheres pelas Mulheres (MPM) se insere. Resultado de uma parceria entre a Universidade Federal do Paraná, a Pontifícia Universidade Católica do Paraná e a Ordem dos Advogados do Brasil - Seção do Paraná, o Mulheres pelas Mulheres é composto por advogadas, professoras e acadêmicas de Direito, que se reuniram no início de 2014 buscando dar visibilidade e voz a mulheres muitas vezes esquecidas e silenciadas; não raro pelos próprios grupos feministas que não as reconhecem como suas iguais (Birolli, 2013).

Como forma de contestação das "comemorações" no Dia Internacional das Mulheres (destinado somente a certas mulheres), foi realizado o 10 Mutirão Carcerário pelo Projeto MPM nas unidades prisionais femininas do Paraná, situadas em Piraquara e Curitiba. A realidade encontrada dentro dos muros do cárcere demonstrou que diversas questões eram merecedoras de atenção: a grande maioria das internas não possuía defesa constituída, muitas desconheciam o andamento de seus processos criminais. Em determinados casos, foi difícil identificar o real motivo pelo qual a mulher encontrava-se detida. Para além da questão jurídica, as péssimas condições de higiene, a precária alimentação e o abandono material e afetivo se mostraram como questões pulsantes dentro das penitenciárias femininas paranaenses, fenômeno esse que se espraia para o âmbito nacional.

A esse 10 Mutirão seguiram-se outros, com o aprimoramento dos instrumentos de pesquisa empírica e dos olhares que se lançaram a respeito da questão. Dois deles, entretanto, servem de base para o presente texto: a) uma rodada de entrevistas com mulheres que visitam pessoas privadas de liberdade; e b) duas rodadas de entrevistas com mulheres grávidas e mulheres com bebês nascidos, enquanto presas.

Assim, o que, no início, era somente um atendimento jurídico (por meio de atuações pontuais, como a formulação de requerimentos para a concessão de 
benefícios da execução da pena) transformou-se a um só tempo em mecanismo de pesquisa empírica, com o objetivo de traçar um perfil da mulher presa no Paraná e uma forma de intervenção política. Intervenção que se deu ao relatar aos órgãos do executivo e do sistema de justiça criminal todas as agruras e sofrimentos latentes nas unidades prisionais que mantêm mulheres privadas de liberdade, além de judicializar algumas questões.

As problemáticas condições das penitenciárias femininas paranaenses não se distinguem, no entanto, do grave cenário verificado no contexto carcerário nacional. Não fosse isso, o perfil da população carcerária feminina também não se distancia daquele que é percebido nas unidades masculinas, sendo constituída majoritariamente por pessoas jovens, negras, de baixa ou nenhuma escolaridade. Não se podendo fechar os olhos para a sobreposição das questões de classe e raça, interseccionadas também pelas de gênero.

No caso das mulheres, os dados sistematizados pelo DEPEN apontam que 50\% da população carcerária feminina sequer tinha o ensino fundamental completo, enquanto apenas $11 \%$ havia completado o ensino médio. A maior parte das mulheres encarceradas possui entre 18 e 29 anos, e duas em cada três são negras (Brasil, 2015a).

A grande diferença está, entretanto, nos tipos penais que levam mulheres e homens à prisão e as peculiaridades de seu cometimento. Não obstante a tradicional associação da criminalidade feminina a delitos relacionados ao cuidado da família e do lar (como os delitos de aborto, infanticídio e maus tratos, por exemplo), a realidade do cárcere demonstra que, em sua absoluta maioria, o aprisionamento de mulheres está diretamente associado ao tráfico de drogas. Longe de querer indicar um maior acesso ao espaço público, a relação com as drogas evidencia fraturas sociais que impõem um cenário de violência e de pobreza extrema, além de reforçar uma certa divisão sexual do trabalho ilícito, já que a elas são destinados os mais baixos postos em organizações, ou ainda as tarefas mais suscetíveis de serem interceptadas pelas ações policiais ou de agentes do sistema penitenciário.

Nesse cenário, porém, a interseção entre os discursos das mulheres que visitam pessoas privadas de liberdade (as quais se destinam quase que totalmente aos homens presos) e o das mulheres que foram presas pelo delito de tráfico de drogas enquanto estavam grávidas, cujos relatos e informações parecem indicar um padrão, uma série de histórias que se repetem e que, para além, das questões da intervenção do sistema punitivo sobre as mulheres, a partir dos baixos postos ocupados tanto no trabalho lícito quanto no ilícito, evidenciam a utilização de seus corpos para o trânsito de drogas.

\section{Recorte da pesquisa: mulheres privadas de liberdade e mulheres que visitam pessoas privadas de liberdade}

A pesquisa realizada pelas integrantes do Projeto MuIheres pelas Mulheres nas prisões femininas no Estado do Paraná, inicialmente, não tinha como foco específico as gestantes e as mulheres que estavam recolhidas juntamente com suas crianças dentro das penitenciárias. Primeiramente, buscou-se fazer uma análise geral da população carcerária das unidades femininas localizadas na Região Metropolitana de Curitiba e na própria capital, visando identificar, dentre alguns fatores, a sua condição de atendimento jurídico, as principais causas do encarceramento, bem como a realidade em que tais mulheres viviam antes da prisão e que enfrentavam no decorrer do encarceramento.

Assim, foram elaborados questionamentos a respeito do(s) crime(s) pelo(s) qual(is) estava(m) presa(s), cidade de origem, renda média familiar, idade, escolaridade, quantidade de filhos/filhas, possibilidade de contratação de profissional da advocacia, recebimento de visitas (comuns e íntimas), entre outros.

\subsection{Epistemologia feminista}

Nesse ponto, necessário esclarecer que a pesquisa aqui apresentada seguiu métodos de colheita e análise de dados próprios daquilo que vem se chamando de epistemologia feminista, entendida como uma nova forma de se fazer ciência, que toma por base as teorias de gênero, permitindo uma análise interseccional, que leva em consideração as construções históricas, sociais e políticas de determinado "objeto de estudo" (Matos, 2008, p. 336).

Idealizada a partir dos movimentos de mulheres e fe- 
ministas, tal epistemologia propõe uma alternativa a um modelo científico único, pretensamente universal e generalizante. Isso porque, ao adotar uma concepção de ciência marcada por uma suposta neutralidade e capaz de ser validada a partir de determinados critérios, o modo tradicional de produção de conhecimento acabou por excluir pessoas marginalizadas (aquelas que não tinham acesso aos lugares próprios do saber ou, pelo menos, do saber tradicional). Nesse sentido, a adoção de uma epistemologia feminista - enquanto uma epistemologia pensada a partir das margens (Castro; Egger, 2012) - é capaz de permitir a releitura de diversos saberes tidos como válidos e verdadeiros a partir de pontos de vistas distintos.

Assim, essa nova forma de produção do conhecimento possui como fonte principal as experiências próprias das pessoas historicamente excluídas dos espaços de saber (e, consequentemente, de poder). Experiências essas tecidas no âmbito privado, no cotidiano simples, e por isso, negligenciadas, invisibilizadas e consideradas como não-válidas para a produção da "verdade científica” (Castro; Egger, 2012).

O histórico confinamento das mulheres ao âmbito doméstico ensejou a produção de saberes que não são considerados como válidos pelo padrão científico tradicional, mas que são relevantes para entender o percurso de uma (ou várias) história(s) das mulheres - o que também é necessário para o estudo a respeito do(s) feminino(s) e do seu lugar na sociedade contemporânea.

É a partir do fortalecimento da(s) epistemologia(s) feminista(s), que devem se admitir múltiplas para não incorrer na pretensão universalizante que criticam, que diversos estudos de gênero começaram a ter lugar em âmbitos considerados como majoritariamente masculinos, como é o campo do Direito Penal e da Criminologia, por exemplo (Cortina, 2015). A análise das relações entre as mulheres e o sistema de justiça criminal é, nesse contexto, a demonstração de uma nova forma de fazer ciência, que permite um olhar diversificado sobre fenômenos antes ignorados ou pensados a partir de uma visão própria do imaginário androcêntrico.

Entretanto, mesmo com o crescimento de pesquisas e estudos do tipo no cenário criminológico brasileiro acerca do tema (Espinoza, 2004) ou de outros sa- beres (Diniz, 2015; Queiroz, 2015) é perceptível que a questão da maternidade no cárcere ainda é tema invisibilizado na academia, mesmo com trabalhos recentes de fôlego, a exemplo de Dar à luz na sombra: condições atuais e possibilidades futuras para o exercício da maternidade por mulheres em situação de prisão (Brasil, 2014). Essa constatação, associada à expressiva quantidade de mulheres grávidas e de crianças dentro das penitenciárias paranaenses fizeram com que, no ano de 2015, esses grupos se tornassem o foco da pesquisa realizada pelo Mulheres pelas Mulheres; demanda que também veio da própria administração penitenciária ante o crescimento do número de mulheres grávidas e, posteriormente, as que então vem a ficar com as crianças (nascidas no período da prisão) até os 6 anos de idade.

Dessa forma, priorizou-se o atendimento às mulheres pertencentes a essas duas categorias, em entrevistas realizadas durante quatro mutirões no segundo semestre do ano de 2015.

\subsection{Local da Realização da Pesquisa}

o Complexo Penitenciário do Estado do Paraná, situado em Piraquara, tem a maior concentração de pessoas privadas de liberdade do Estado com mais de 10.000 pessoas dispersas em 6 unidades prisionais; duas dessas unidades são destinadas, exclusivamente, para mulheres: (i) a PFP - Penitenciária Feminina de Piraquara e a (ii) PCEFem - Penitenciária Central Feminina de Piraquara. As demais unidades são para homens privados de liberdade: (i) a PCE - Penitenciária Central do Estado, com a maior população carcerária masculina de todo o Estado, com aproximadamente 1.500 homens; (ii) a PEP - Penitenciária Estadual de Piraquara; (iii) a PEP 2 - Penitenciária Estadual de Piraquara 2, e a CCP - Casa de Custódia de Piraquara. Em tese, a CCP e a PCEFem estariam destinadas às pessoas privadas de liberdade em situação provisória (DEPEN-PR). Na prática, não há essa efetiva separação. Próximo à Piraquara, em Pinhais, fica a unidade do Complexo Médico Penal do Estado.

\subsubsection{Entrevistas com as mulheres privadas de liberdade grávidas e com as mulheres que estão com crianças}

Cumpre esclarecer, neste ponto, que no Paraná - no período em que as entrevistas foram feitas, nos me- 
ses de outubro e novembro de 2015 - a questão da gestação e maternidade estava assim organizada: (i) gestantes: as mulheres presas, provisória ou definitivamente, que estivessem grávidas, independentemente do estágio e da condição da gravidez, eram encaminhadas ao Complexo Médico-Penal (CMP), aonde deve(ria)m receber toda a assistência médica relacionada ao pré-natal; (ii) mulheres com bebês: as mulheres, após darem à luz aos seus/suas filhos/fiIhas no Hospital Angelina Caron, eram encaminhadas - às vezes no mesmo dia do parto cesáreo ou natural - à Penitenciária Feminina de Piraquara (PFP).

À época dos atendimentos, as gestantes, por força de eventos externos ao próprio âmbito da Justiça Estadual (como as Operações Lava Jato, Quadro-Negro e Publicano, por exemplo), estavam recolhidas na mesma ala em que estavam as mulheres submetidas a medidas de segurança e as internas levadas ao Complexo Médico Penal para o tratamento de doenças (inclusive, infectocontagiosas) ou a realização de exames e cirurgias.

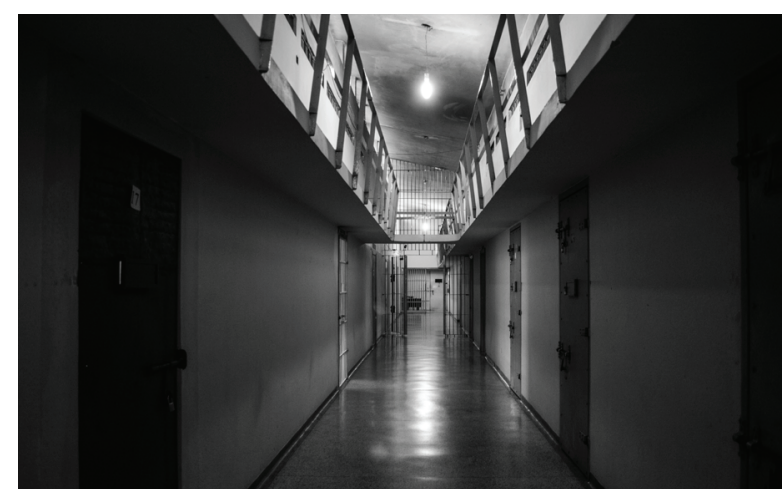

Corredor da Ala Feminina do CMP. Fotografia por Valéria Kotacho Lopes

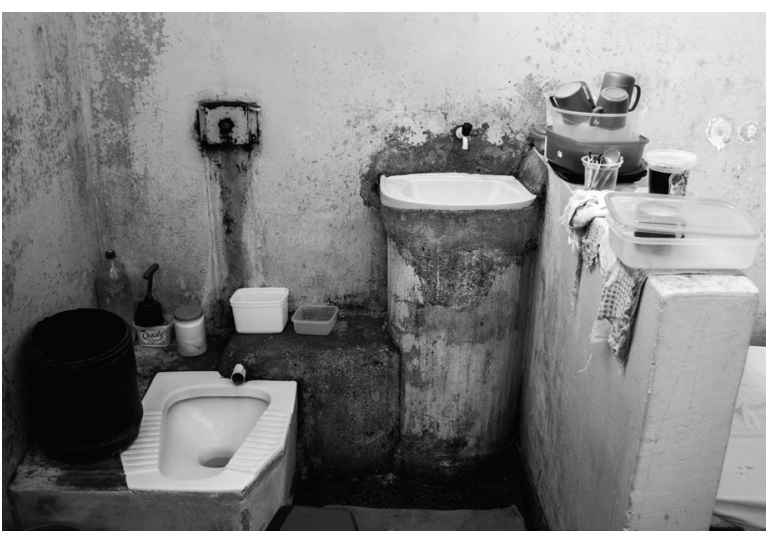

Cela onde ficavam as mulheres grávidas no CMP. Fotografia por Valéria Kotacho Lopes
As entrevistas foram feitas, então, nessas duas unidades (CMP e PFP).

Antes de se iniciarem os trabalhos, era informado tanto pelas agentes penitenciárias femininas, quanto pelas acadêmicas de que a realização da entrevista era feita de forma voluntária. Cada duas acadêmicas, supervisionadas, atendiam uma interna apresentando a proposta de trabalho e registravam, mais uma vez, a não obrigatoriedade de sua realização. No CMP, somente uma interna recusou-se a participar da entrevista, não informando o motivo. Na PFP, todas as internas participaram das entrevistas.

O ambiente usado no CMP era uma sala com carteiras "tipo" sala de aula e não havia a supervisão de nenhuma agente penitenciária, também não houve restrição ao instrumento usado na pesquisa e tampouco exigência de apresentarmos as entrevistas respondidas ou controle sobre o seu conteúdo durante a realização.

Já na PFP, foram três os ambientes usados para as entrevistas: (a) a própria "creche", dado o elevado número de mulheres com crianças; (b) sala destinada à informática; e (c) sala de aula. As entrevistas não tinham a supervisão de nenhuma agente penitenciária, também não houve restrição ao instrumento usado na pesquisa e tampouco exigência de apresentarmos as entrevistas respondidas ou controle sobre seu conteúdo durante a realização. Registre-se, no entanto, que pelo trânsito elevado de pessoas (das pesquisadoras, das próprias internas e de profissionais da advocacia - a sala do parlatório era próxima da sala de informática) a presença das agentes penitenciárias era constante, mas não permaneciam na sala de entrevista durante a sua realização.

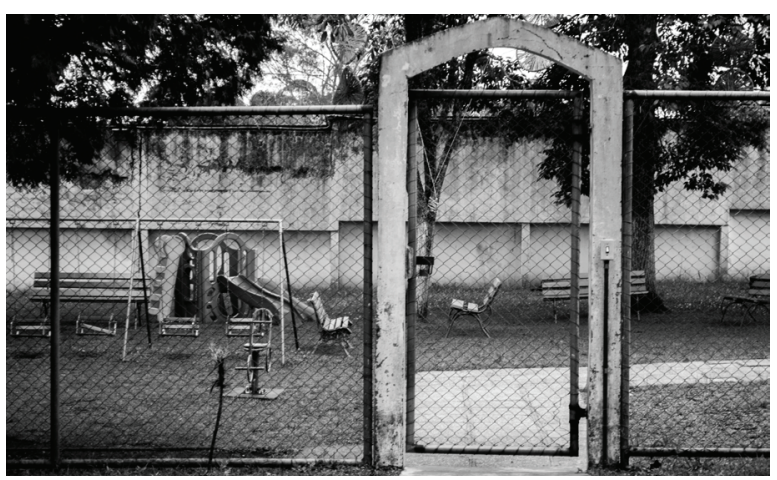

Entrada da Creche. Fotografia por Valéria Kotacho Lopes 


\subsubsection{Entrevistas com as mulheres que} visitam pessoas privadas de liberdade O local de sua realização foi na entrada do Complexo Penitenciário do Estado, por onde passam, obrigatoriamente, todas as visitas de cada uma das unidades que o compõem. A precariedade do local fez com que as pessoas que se encontravam na fila fossem entrevistadas em tal local (também porque não queriam perder o seu lugar para a entrada no Complexo).

Essa única rodada de entrevistas foi realizada num domingo, durante o período de $2 \mathrm{~h} 30 \mathrm{~min}$, em que as visitas eram destinadas à PEP I, à PCE (unidade masculina) e à PFP (conforme cronograma do DEPEN). Da mesma forma que a pesquisa anterior, foi ressalvada a voluntariedade em sua participação, bem como a não obrigatoriedade em responder a todas as questões.

\subsection{Da Pesquisa com as mulheres privadas de liberdade gestantes e com crianças.}

A participação e a resposta a qualquer uma das perguntas elaboradas era facultativa, como assinalado, $\mathrm{e}$ isso fora informado às entrevistadas primeiro de forma geral e depois individualmente. Ao entrevistá-las seguia-se um roteiro previamente estabelecido, por meio da elaboração de um questionário, o qual abordava desde a situação socioeconômica e a escolaridade da interna até as circunstâncias específicas em que se deu a prisão. Ponto importante para esse texto.

No decorrer da pesquisa, as próprias entrevistadas apontaram as precárias condições de estrutura física da unidade - que é a mais antiga do Estado - e o abandono afetivo e material de que padecem. Não faltaram, ainda, relatos de casos de internas que deram à luz dentro das celas ou que só foram encaminhadas ao hospital quando a gestação já havia superado 40 semanas, ou ainda quando havia sangramento intenso. ${ }^{6}$

Não obstante tais bebês fiquem em local próprio, com a mediação de estrutura e recursos, é necessário consignar que a "creche" (cuja própria nomenclatura constitui-se num problema) não se distancia da ló-

6 Duas crianças, entretanto, nasceram enquanto suas mães estavam em liberdade. De acordo com os relatos, duas internas recolhidas na PFP à época dos atendimentos conseguiram trazer consigo seus filhos no momento de suas prisões em flagrante, levando-os, posteriormente, à Penitenciária Feminina do Paraná. gica estrutural inerente a uma prisão. Além de estar localizada em região afastada - de escolas, hospitais, etc. - e de não ter um corpo próprio de médicos em tempo integral, especialmente pediatras, apesar do esforço da Diretoria e do corpo de agentes penitenciários, tal ambiente não é capaz de atender ao vetor absoluto da ordem constitucional brasileira (conforme dispõe o Artigo 227 da Constituição da República ${ }^{7}$ ), que é a proteção ao melhor interesse das crianças e dos adolescentes.

Diante desse contexto, as integrantes do Projeto Mulheres pelas Mulheres decidiram elaborar requerimentos para a concessão de prisão domiciliar às internas atendidas nos mutirões carcerários de 2015, provisórias ou condenadas, que não possuíam defesa constituída e que manifestaram o seu desejo para tanto. Tendo como fundamentos a Constituição da República, a Convenção de RIAD, as Regras de Bangkok, o Estatuto da Criança e do Adolescente e a Lei Federal $n^{\circ} 13.257 / 2016$, foram formulados 32 pedidos de prisão domiciliar, que buscavam atender justamente os princípios da proteção integral à criança e da satisfação do seu melhor interesse.

Dos 32 requerimentos protocolados, apenas 03 foram deferidos em primeira instância (1 na Vara de Execuções Penais e 2 nas Varas Criminais de origem, já que eram presas provisórias). Após o indeferimento dos pedidos, foram impetrados 6 pedidos de Habeas Corpus e interpostos 20 recursos de Agravo em Execução. Dos HCs, somente dois foram concedidos (que foram relatados pelo mesmo Desembargador do TJPR), e um foi julgado prejudicado (uma vez que a interna foi condenada em regime aberto). Dos Agravos julgados até o momento, todos restaram indeferidos (17 recursos). Foram interpostos 3 Recursos Ordinários em Habeas Corpus, dos quais apenas um teve a liminar concedida - mas, aguarda a decisão de mérito -, um foi indeferido e o outro julgado prejudicado por ter a requerente sido absolvida na sentença; todos

7 Art. 227. É dever da família, da sociedade e do Estado assegurar à criança, ao adolescente e ao jovem, com absoluta prioridade, o direito à vida, à saúde, à alimentação, à educação, ao lazer, à profissionalização, à cultura, à dignidade, ao respeito, à liberdade e à convivência familiar e comunitária, além de colocá-los a salvo de toda forma de negligência, discriminação, exploração, violência, crueldade e opressão. (Redação dada Pela Emenda Constitucional nº 65, de 2010). 
os 16 Recursos Especiais tiveram seguimento negado pela Corte, tendo sido interposto dois Agravos ao STJ, que também não obtiveram êxito.

No dia 03 de agosto, o Projeto Mulheres pelas Mulheres entregou pessoalmente um relatório para o Secretário-Geral da Organização dos Estados Americanos (OEA), na sede da Ordem dos Advogados do Brasil - PR, denunciando o tratamento dispensado pelo judiciário paranaense à causa das mulheres presas, a partir dos resultados obtidos após os ajuizamentos dos pedidos de domiciliares. Após a entrega desse relatório foi realizada, pelo Tribunal de Justiça em parceria com outros órgãos da execução da pena, um mutirão carcerário na Penitenciária Feminina do Paraná concedendo o benefício de prisão domiciliar para a maioria das muIheres com bebês. Das mulheres atendidas pelo Projeto Mulheres pelas Mulheres que estavam aguardando o julgamento no STJ, 12 receberam o benefício em virtude da ação organizada pelo TJPR.

\subsection{Da Pesquisa com as mulheres que visitam pessoas privadas de liberdade}

O objetivo da pesquisa, com as pessoas que visitam pessoas privadas de liberdade era o de mapear as condições da chamada revista vexatória. Durante a pesquisa, que foi realizada em maio de 2015, verificaram-se, entretanto, algumas questões sobre a revista vexatória (não propriamente a condição vexatória da revista, ponto de pesquisa na ocasião) que viriam a se entrecruzar com o que seria visto na coleta de dados com as mulheres grávidas e com crianças.

Nesse ponto, vale esclarecer que a revista para o ingresso no sistema prisional do Paraná não é feita de modo uniforme (mesmo que no tal Complexo Penitenciário): algumas unidades dispõem do sistema scanner corporal (ou body scanner) e outras usam o sistema de raquete e agachamento. Mas, desde logo, importante ressaltar que as mulheres grávidas, pela questão do bebê, não passam pelo body scanner.

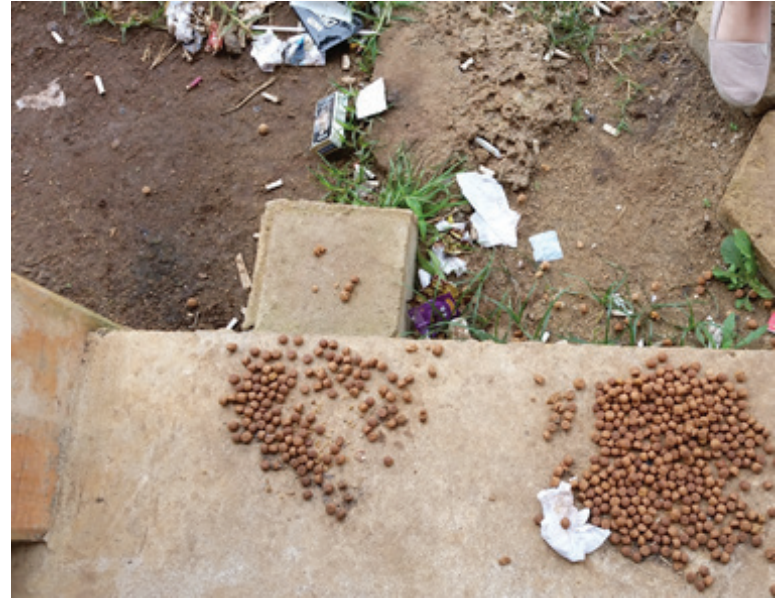

Chão próximo ao banheiro no local de espera para o acesso aos banheiros da entrada do CMP. Fotografia por Priscilla Placha Sá

\section{Sistematização dos dados colhidos}

\subsection{Da coleta de dados obtidos com as mulheres privadas de liberdade}

Os dados levantados, embora possuam um recorte próprio, confirmaram a pesquisa apresentada pelo relatório Infopen Mulheres 2015 do Ministério da Justiça (Brasil, 2015a), demonstrando que a população carcerária feminina é majoritariamente jovem, não branca e de baixa escolaridade e baixa renda familiar, e que se encontra presa provisoriamente ou em definitivo por delitos relacionados ao tráfico de drogas.

As entrevistadas no Complexo Médico-Penal foram as grávidas, as mulheres em medida de segurança e para tratamento de doença, interessando aqui os dados apenas das grávidas.

No CMP a faixa etária ${ }^{8}$ das grávidas ficou entre 18 e 35 anos e na PFP não foi diferente, ficando entre 18 e

8 Todas as mulheres atendidas no CMP responderam a sua idade e na PFP apenas $8 \%$ não responderam. 
36 anos, refletindo o resultado obtido no relatório do Mistério da Justiça em que $68 \%$ das mulheres encarceradas possuem idade entre 18 e 34 anos.
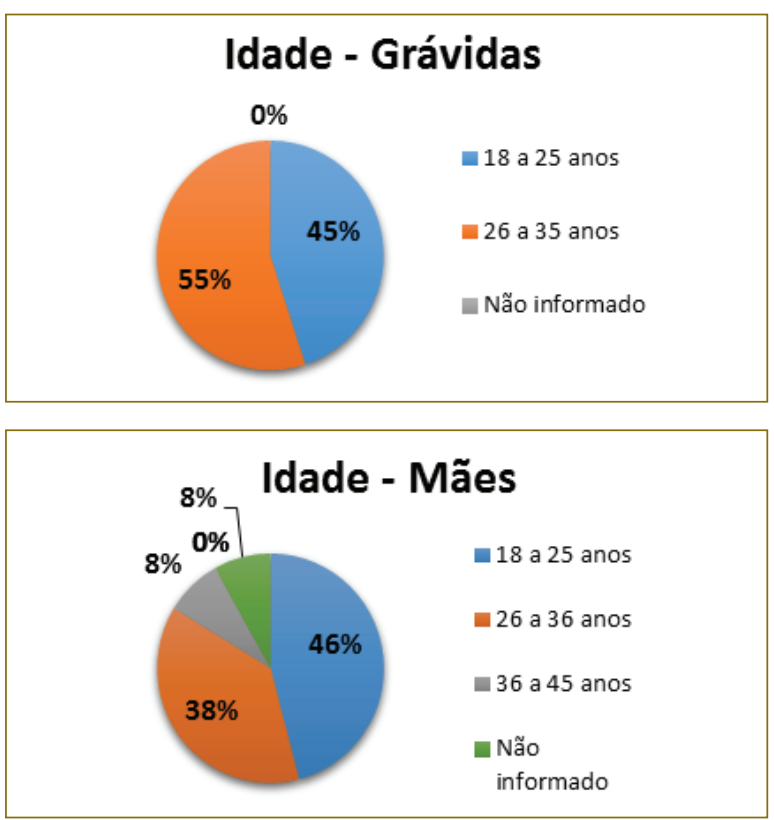

A maternidade constitui-se como regra entre os dois Grupos, ainda que grande parte das mulheres seja jovem. Ademais, a maioria das entrevistadas tinha mais de um filho. Tais circunstâncias demonstram o pouco acesso que essas mulheres possuem à orientação e ao planejamento familiar, muito provavelmente em virtude da baixa renda e pouca escolaridade.

As proporções se confirmam novamente quando comparamos o índice de escolaridade das mulheres encarceradas do Brasil $^{9}$ e das mulheres grávidas e com bebês do Paraná: cerca de 50\% delas não chegaram a concluir o Ensino Fundamental, o que significa que essas mulheres ficaram menos de nove anos na escola.

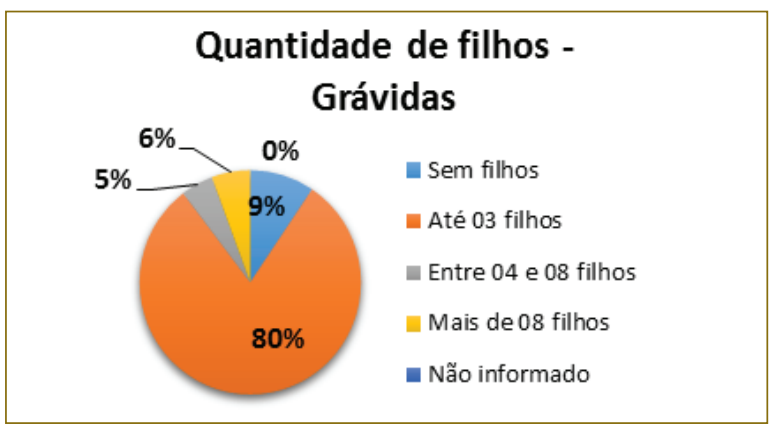

9 Conforme o Infopen Mulheres (Brasil, 2015a), 4\% são analfabetas, $50 \%$ das mulheres encarceradas possuem o Ensino Fundamental Incompleto e apenas $11 \%$ completaram o Ensino Médio.

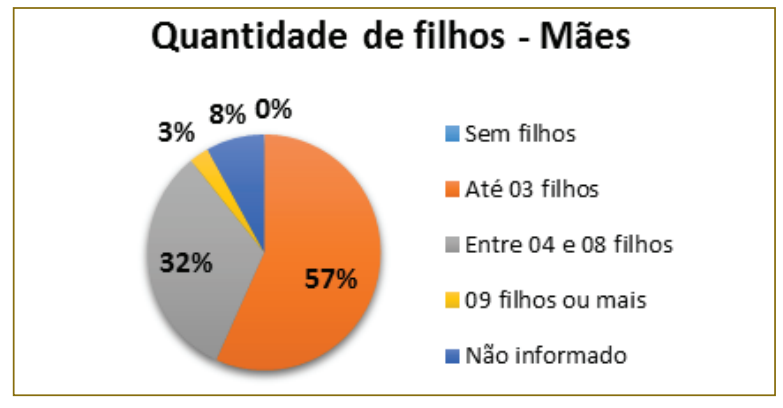

*Uma das mulheres, com 36 anos de idade, declarou ter 15 filhos
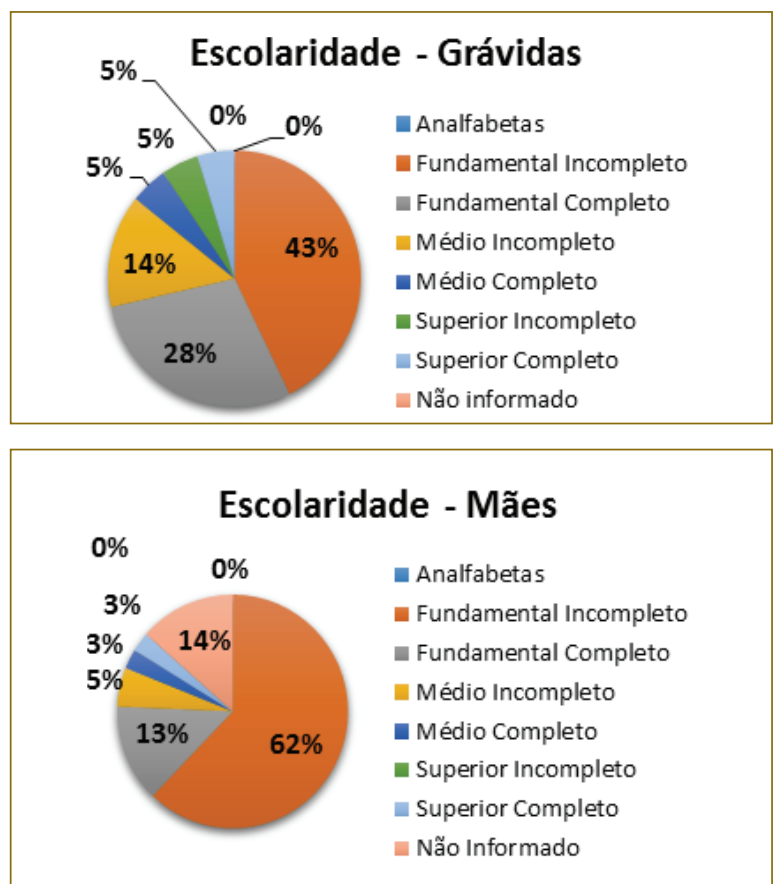

O baixo índice de escolaridade dessas mulheres reflete diretamente em sua renda familiar e, consequentemente, nos seus empregos, que são em sua maioria informais - quando não, ilícitos.

Ademais, a sociedade paradoxal em que vivem, que por ser sexista e patriarcal as exclui do mercado de trabalho, faz com que, ao mesmo tempo, muito em virtude do alto índice de encarceramento e de extermínio do homem negro, essas mulheres sejam "chefes de família" e, tenham que sustentar sozinhas suas famílias desde muito jovens. Sem carteira as$\operatorname{sinada}^{10}$, com filhos para alimentar e uma gravidez

10 Conforme os atendimentos, no CMP, 09\% das mulheres grávidas atendidas não possuem filhos, $80 \%$ possuem até 03 filhos, $05 \%$ possuem entre 04 e 08 filhos e $06 \%$ possuem mais de 08 filhos. Já na PFP, 57\% mulheres possuem até 03 filhos, $32 \%$ entre 04 e 08 filhos, $3 \%$ mais de 08 filhos e $08 \%$ não responderam. Demonstrando que desde muito novas essas mulheres já possuem um núcleo 
para terminar, essas mulheres acabam não tendo outra alternativa que o tráfico de drogas. Essa circunstância é confirmada pelos dados levantados (que reafirmam a pesquisa publicada no Infopen ${ }^{11}$ Mulheres), uma vez que mais de $50 \%$ das mulheres são encarceradas pela Lei de Drogas, enquanto o aprisionamento por crimes que culminam em morte gira representa apenas $10 \%$ do total, reafirmando, mais uma vez o perfil da mulher presa.
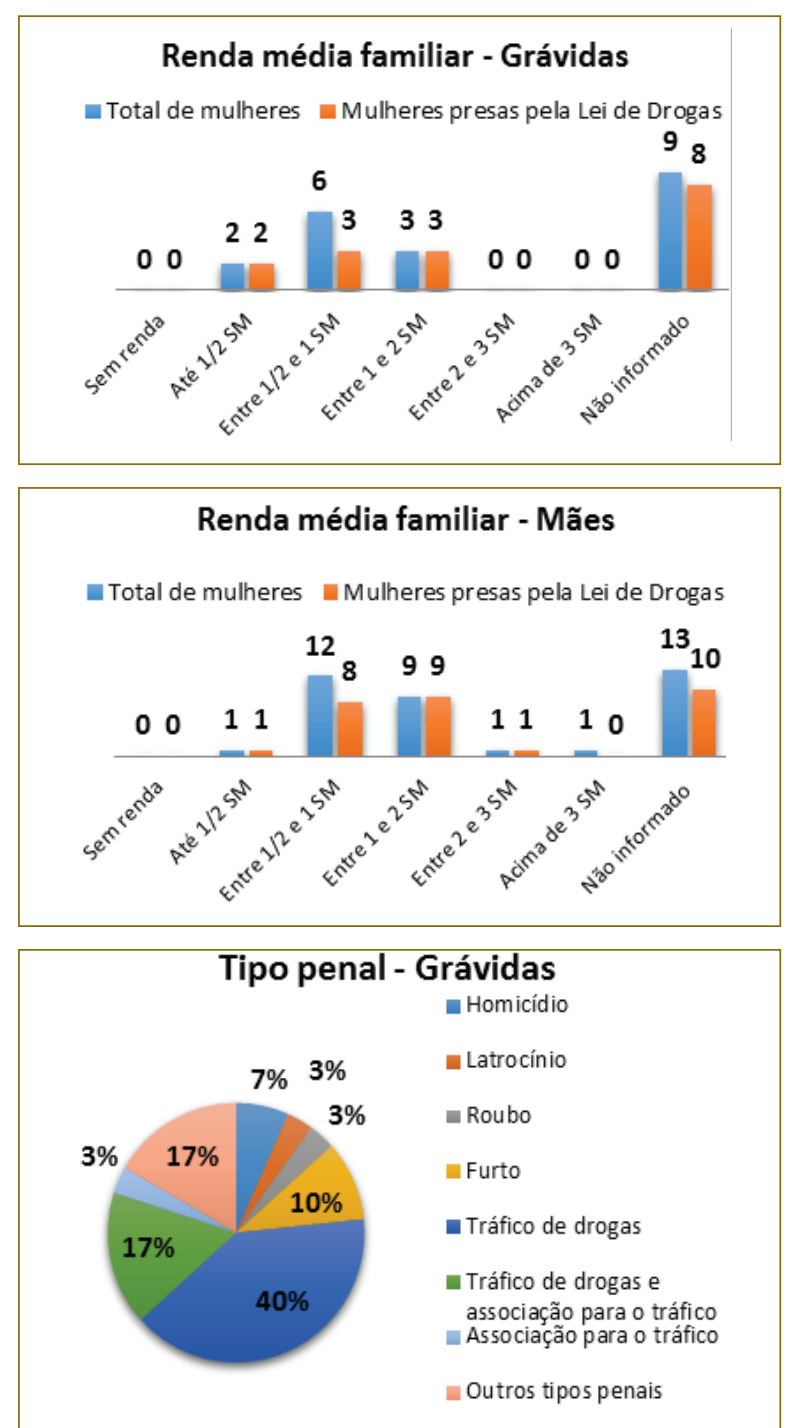

Gráfico por delito. Somente 03 casos de tráfico de drogas estavam relacinados com porte/posse de armas.

familiar, de certa forma, extenso, o qual aliado a dificuldade financeira em que se encontram, torna a vida dessas mulheres bastante difícil e sofrida.

11 Segundo a pesquisa realizada pelo Departamento Penitenciário Nacional, $68 \%$ das mulheres encarceradas no Brasil estão presas pela Lei de Drogas, sendo que apenas 09\% estão presas por tirarem a vida de alguém (02\% latrocínio e 07\% homicídio).

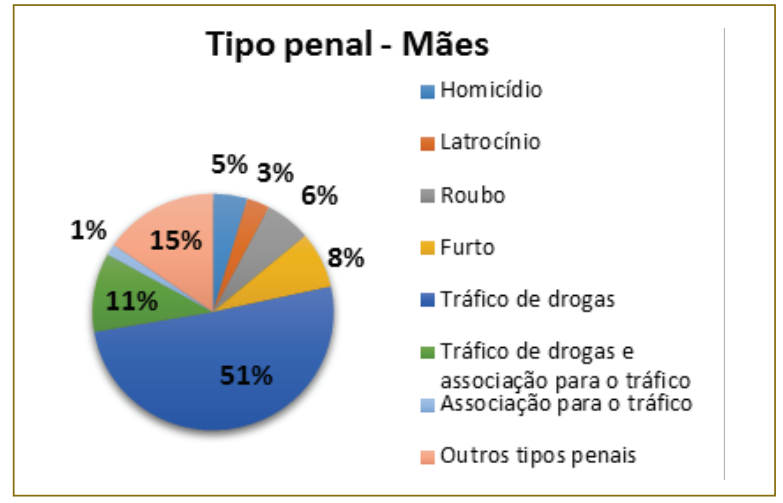

Gráfico por delito

A concentração, no momento de realização da pesquisa, das mulheres grávidas no CMP e das com os bebês nascidos na PFP indica a presença de muitas mulheres vindas do interior do Paraná, que ocupam em ambos os grupos a sua porção majoritária. Essa concentração da população carcerária feminina na capital do estado gera ainda mais abandono afetivo e material e tem justificativa no fato de que estão em Curitiba as duas únicas unidades com (suposta) estrutura para abrigar as mulheres grávidas e as mães com seus bebês. A ausência de unidades com tais características no interior do Paraná só vem a reforçar o caráter masculino do sistema de justiça criminal, demonstrando o descaso e a invisibilidade da questão da mulher encarcerada.

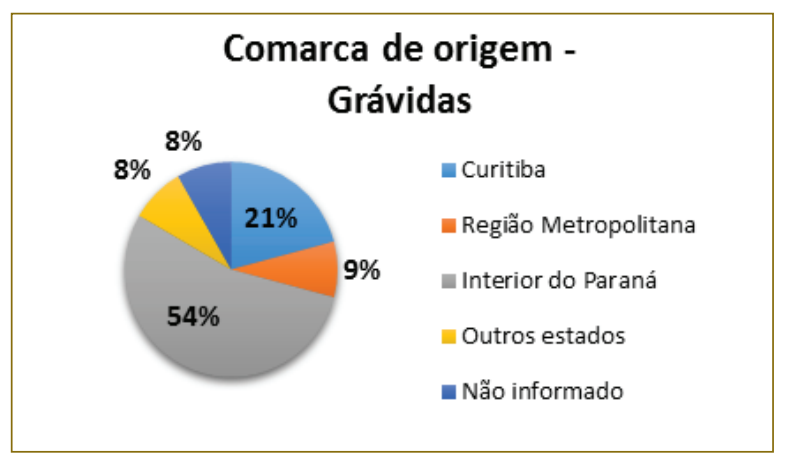

Dado contabilizado por processo de tráfico de drogas.

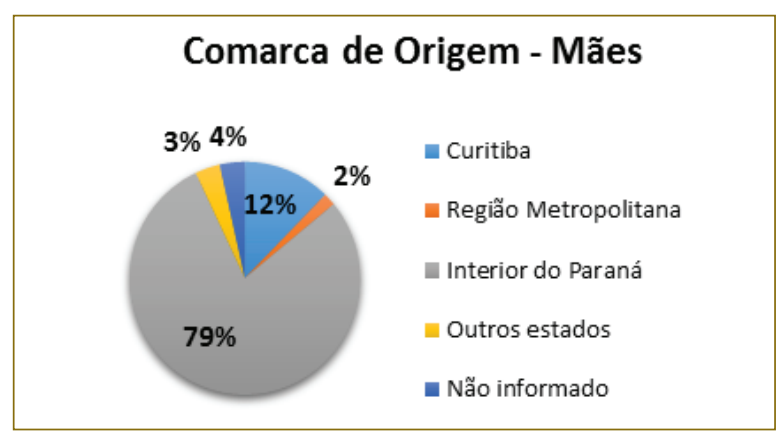

Os dados obtidos a respeito das circunstâncias da prisão, bem como dos locais em que ela ocorreu 
demonstram sua condição subalterna da mulher no tráfico de drogas, a ausência de poder de barganha (corrupção) e a não utilização de armas de fogo.

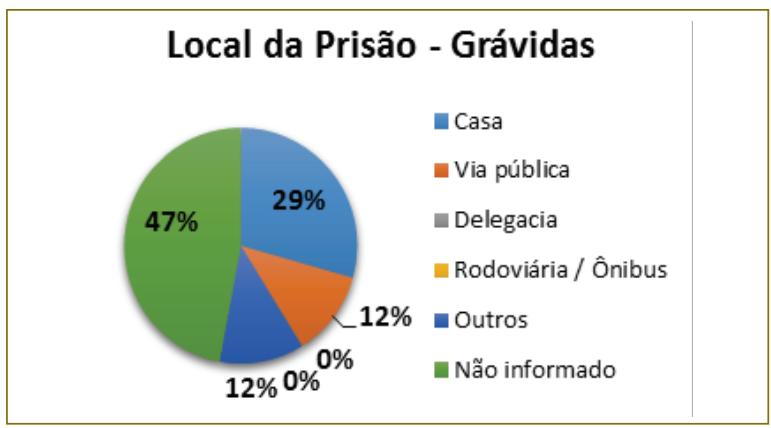

Dado contabilizado por processo de tráfico de drogas

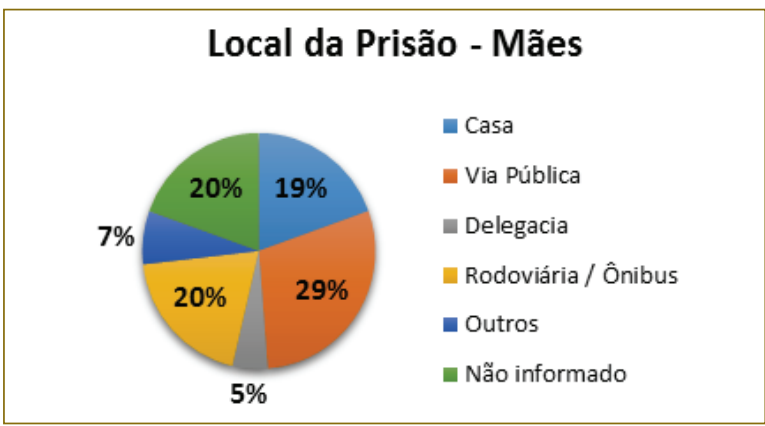

Dado contabilizado por processo de tráfico de drogas

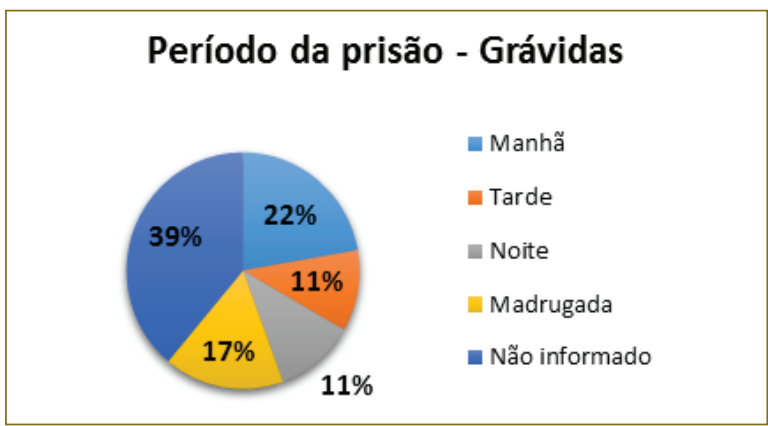

Dado contabilizado por processo de tráfico de drogas.

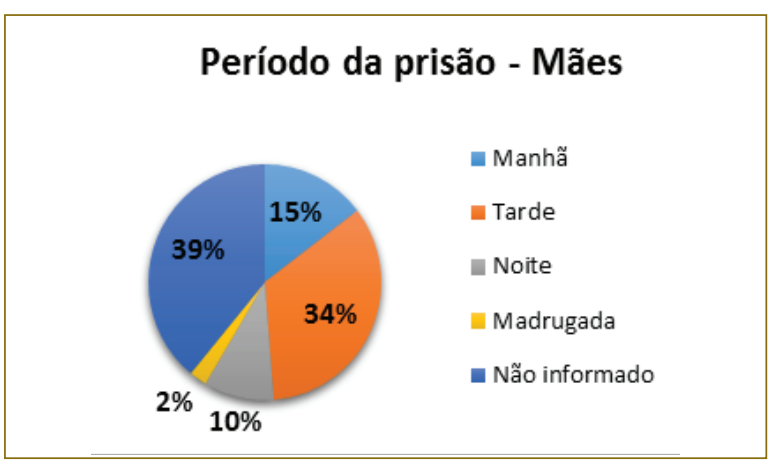

Dado contabilizado por processo de tráfico de drogas

Nesse sentido, a relação das mulheres com o tráfico de drogas não se dissocia dos obstáculos por ela en- frentados em quaisquer outros setores do mercado de trabalho - formal ou informal. A elas são destinados os postos mais baixos, vulneráveis e perigosos, de modo a estarem sempre em constante risco - de vida, de serem presas, etc. $\mathrm{O}$ acesso das mulheres ao espaço público, e ao espaço público ilícito, mais especificamente, não significa, assim, rompimento de amarras e preconceitos inerentes a um contexto social de dominação masculina. Pelo contrário, a vinculação ao mercado ilícito de entorpecentes apenas reforça tais permanências.

Para além desse reforço da manutenção da divisão sexual do trabalho (no caso, ilícito), a relação das mulheres com o tráfico de drogas evidenciou o despreparo das polícias para lidar com a questão da criminalidade feminina. Nesse sentido, ainda que exista determinação legal para que a prisão de mulheres seja feita por policiais também mulheres ou que, ao menos, estejam presentes, verifica-se que na maioria dos casos isso não ocorre.

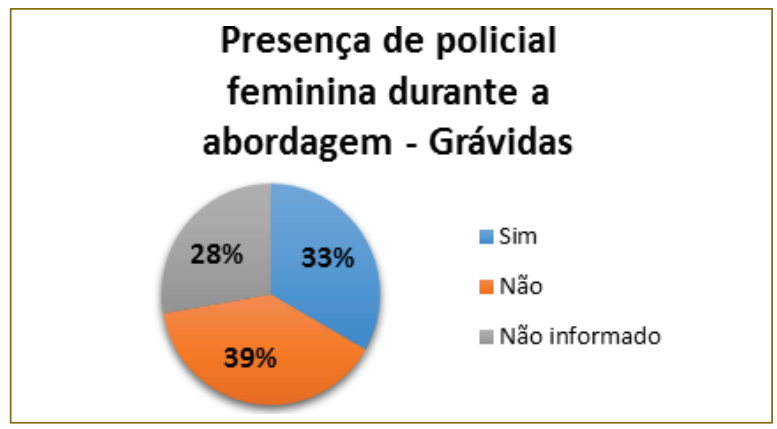

Dado contabilizado por processo de tráfico de drogas.

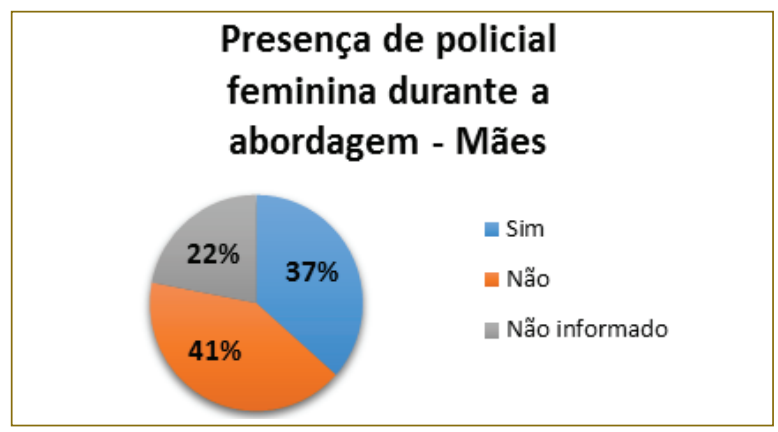

Dado contabilizado por processo de tráfico de drogas

Outro fator que salta aos olhos na análise dos dados obtidos é a abordagem violenta da polícia, especialmente, por membros da Polícia Militar, que é a que realiza a função de "polícia de repressão", mesmo em se tratando de mulheres grávidas. 


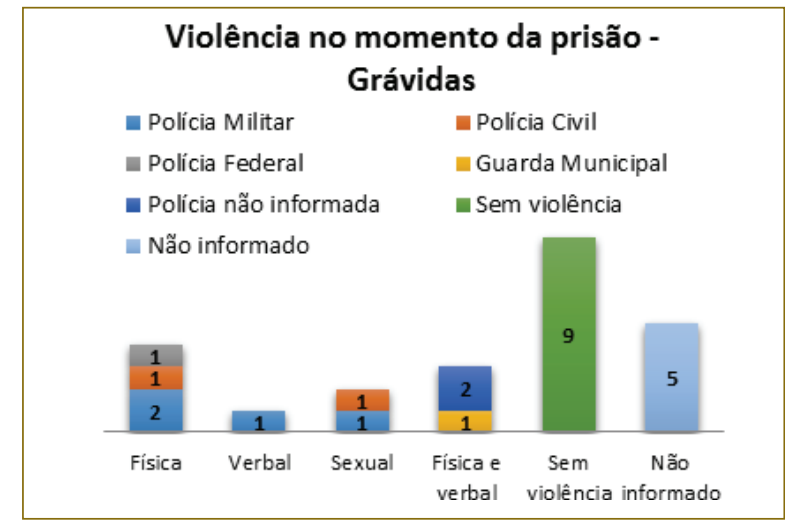

Dado contabilizado por processo de tráfico de drogas.

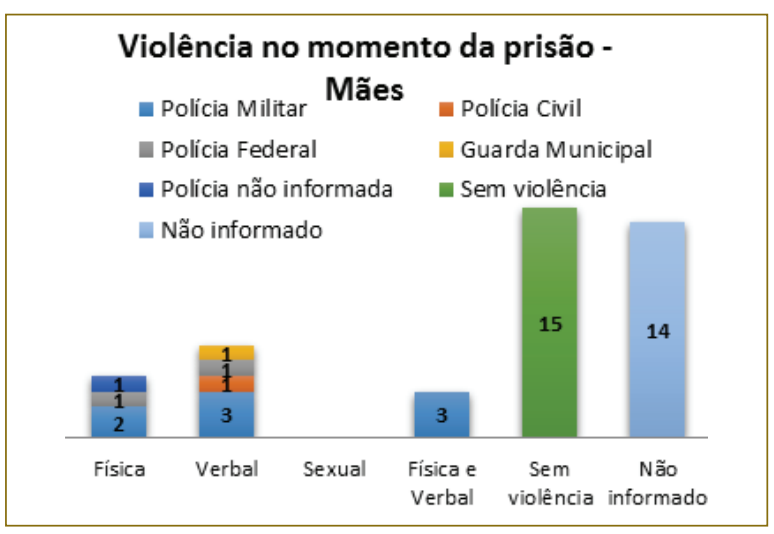

Dado contabilizado por processo de tráfico de drogas. Para além dos processos de tráfico, houve mais 04 casos em que foi relatada violência física, no momento da prisão.

Da análise de todos os dados colhidos, verificamos que a recente e complexa relação do feminino com o tráfico de substâncias ilícitas parece ser, então, uma questão meramente econômica ou afetiva. Para algumas mulheres, a entrada no tráfico está vinculada a um relacionamento, tanto por laços de afeto (no sentido de acompanhar o companheiro/marido/familiar nas suas atividades) como pela necessidade (ocupar o lugar de uma pessoa que já foi selecionada pelo sistema de justiça criminal). Para outras, entretanto, a relação com o mercado ilícito advém unicamente de uma questão financeira. Seria possível indicar que o ingresso de mulheres no tráfico não significa uma vida com ganhos fáceis, muito menos uma vida de fartura e riqueza. Ao contrário, significa um modo de complementação de renda, uma forma de trabalho aliada a outro de natureza precária e desvalorizada, cujo salário as suas necessidades e da prole.
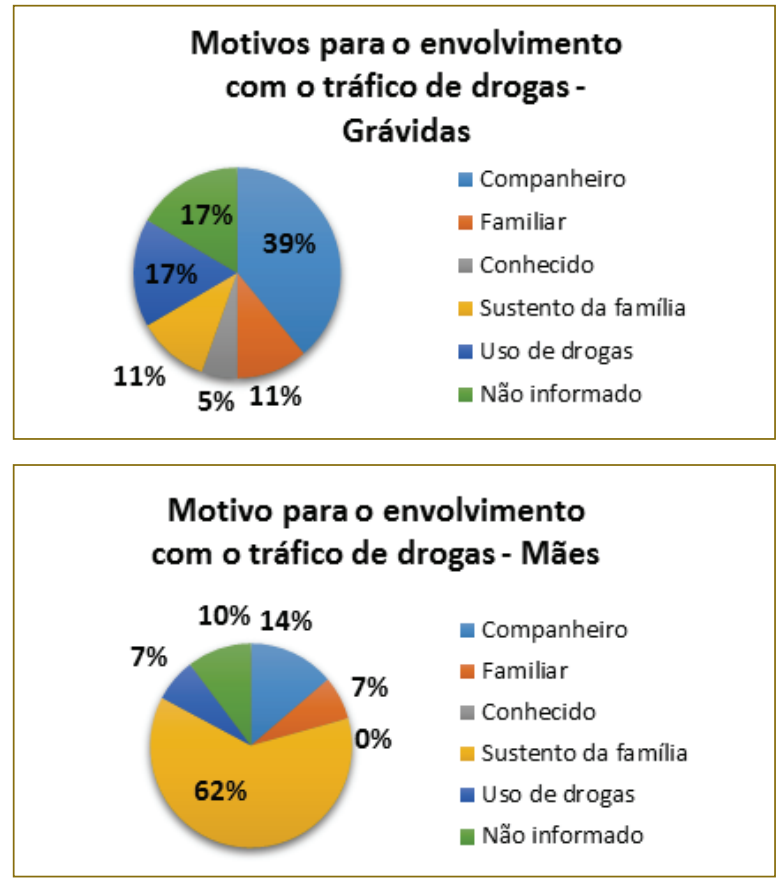

Nesse contexto, a constituição de família monoparental, formada pela mãe e pela prole, intrinsecamente relacionada ao fenômeno da feminização da pobreza, também é elemento que se pode encontrar dentro das penitenciárias femininas paranaenses - assim como também é verificado nas varas de família e entre as pessoas beneficiárias de programas sociais, como o bolsa família. Entre as crianças que nascem e passam os primeiros meses de vida dentro do ambiente prisional, a absoluta maioria não possui o nome do pai em suas certidões de nascimento, conforme se verifica do gráfico abaixo. Tal circunstância é ainda mais grave quando analisada conjuntamente ao fato de que muitas das mulheres privadas de liberdade também não possuem registro paterno e não conviveram com seus pais durante a sua fase de desenvolvimento. Verifica-se, assim, a possibilidade de existência de um ciclo de abandono e de faltas simbólicas que acaba tendo por consequência o traçado de um mesmo caminho, que leva sempre grupos com perfis sócio-familiares à prisão.

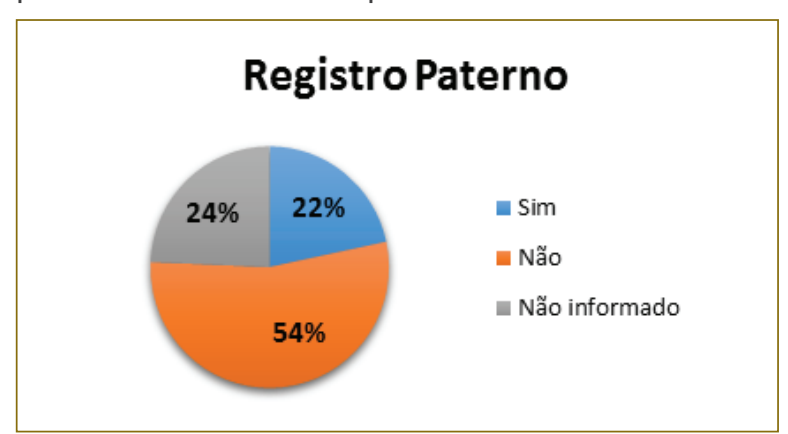




\subsection{Sistematização dos dados das mulheres que visitam pessoas privadas de liberdade.}

Foram entrevistadas 39 mulheres, sendo que: 2 iriam visitar mulheres detidas na PFP, 2 iriam visitar pessoas na PEP I, 22 iriam visitar pessoas na PCE, 9 não quiseram informar a unidade, 3 informaram que iriam em mais de uma unidade e 1 informou que seria a primeira vez a realizar a visita.

As reclamações sobre o sistema de visitas na PCE eram bastante contundentes, apesar de ser realizado por meio de body scanner. Algumas das mulheres relataram que quando seus companheiros, filhos ou familiares estavam na PEP I isso era "mais tranquilo". Algumas disseram que era melhor a raquete ou o espelho porque era menos demorado.

\section{Discussão, cruzamento e análise dos dados colhidos}

A frase que se encontra como epígrafe do presente texto é, também, a sua hipótese, a qual pode ser pensada a partir da intersecção dos dados colhidos: a de que os chamados "comandos" ou "facções" criminosas, que não precisam estar recolhidos necessariamente sob o manto do Primeiro Comando da Capital, "compram" mulheres grávidas.

A entrevistada, autora dessa frase, afirmou ser do "comando", mas que não poderia nos informar de qual e que "a gente já podia imaginar"; e que ela (que estava grávida) foi quem intermediou a "compra de uma grávida", sua amiga, a pedido do irmão, que também era do mesmo "comando" dela.

De outro lado, uma das duas únicas mulheres que foram entrevistadas enquanto esperavam para entrar no sistema para visitar um interno na PEP I afirmou que é corrente o uso de aparelhos celulares pelos presos, e que quando os agentes estão "embaçando" a entrada é só dar uma ligada que eles agilizam. Cumpre registrar que é conhecido no Paraná o fato de que tal unidade prisional seria uma unidade "faccionada".

Usamos isso como hipótese, considerando dois vetores: a) a feminização da pobreza que seria, também, a feminização do tráfico de drogas, fenômeno que tem propiciado o aumento vultoso de mulheres presas por delitos dessa natureza, ainda que em postos subalternos, como "mulas" ou atuando do em uma espécie de "varejo" (poucas quantidades, sem porte de arma e com pouco volume de dinheiro); e b) o tráfico de drogas reproduz não só a lógica da divisão sexual do trabaIho no campo da ilicitude como também usa os corpos femininos e as estereotipias de um feminino ideal para o trânsito de drogas (na rua e no sistema prisional).

O termo feminização da pobreza decorre da percepção de que as mulheres vêm se tornando, ao longo do tempo, mais pobres que os homens por razões diversas, as quais encontram fundamento, principalmente, na "função" atribuída às mulheres nas relações familiares e na sua precária participação no mercado de trabalho - estruturada a partir de um histórico modelo patriarcal de acumulação de capital (Lucas; Hoff, 2008).

Muito embora as mulheres constituam parcela significativa da população assalariada na realidade brasileira, é sabido que a sua remuneração ainda é menor do que a renda percebida por homens em cargos idênticos. Exemplos disso são os dados sistematizados pelo IBGE (2015). O rendimento médio da população masculina ocupada em trabalhos formais é de $\mathrm{R} \$ 2.293,00$, enquanto a renda média feminina nessa mesma categoria é de $R \$ 1.361,00$. Já em relação à população que trabalha de maneira informal, o rendimento médio dos homens é de $R \$ 1.763,00$, enquanto o das mulheres é de apenas R\$ 887,00 (IBGE, 2015, p. 62).

Não fosse isso, os estudos a respeito do tema geralmente relacionam o fenômeno da feminização da pobreza ao crescimento de famílias chefiadas por mulheres. A partir dos dados do IBGE, verifica-se que $29,1 \%$ dos arranjos familiares com pessoa de referência do sexo feminino com filhos possuem renda per capita menor de $1 / 2$ salário mínimo - em relação a arranjos familiares dessa categoria na qual a pessoa de referência é homem, esse índice baixa para 17,2\% (IBGE, 2015, p. 41). Fato que se coaduna, em certa medida, com o perfil das mulheres que já tiveram os bebês e considerando que mais de 50\% não contam com o registro paterno.

É importante ressaltar, nesse ponto, que para a análise de tal fenômeno é imprescindível para que se evitem explicações reducionistas e simplificadoras, buscando 
sempre atentar para as especificidades da condição feminina, (re)produzida por processos multifacetados e legitimados por construções sociais, que não podem ser entendidos como imutáveis (Macedo, 2008, p. 62).

Nesse sentido, é necessário perceber que aspectos próprios da desigualdade de gênero, como as dificuldades de acesso ao espaço público, a atribuição de tarefas de cuidado entendidas como funções naturais femininas e a administração de "sua dupla participação nas esferas de produção e da reprodução, em condições desfavoráveis aos homens que também são chefes de família" (Macedo, 2008, p. 41) (sem que tenham o auxílio de outra pessoa, como é o caso desses homens, que não raro contam com a ajuda de uma mulher tanto nos espaços domésticos como no trabalho), são circunstâncias fundamentais que podem aproximar as mulheres de uma situação de pobreza e vulnerabilidade.

Assim, a pauperização de mulheres, como fenômeno que se espraia para vários campos do trabalho (formal e informal), alcança também o trabalho ilícito, influenciando, inclusive, na decisão de cometer ou não um delito a partir do oferecimento de quantia em dinheiro para tanto. Em um cenário de pobreza, de precarização do trabalho e de responsabilidade direta pelo cuidado com a casa e com os filhos, as propostas de trabalho (mesmo que sabidamente ilícito) como o que se coletou das falas das entrevistadas, demonstram a enorme dificuldade em sua recusa. Tanto mais num cenário de crise econômica prolongada, em que os postos de trabalho formal são reduzidos, além da resistência em contratar mulheres que estão grávidas.

O fenômeno da feminização da pobreza está assim intimamente relacionado ao aprisionamento feminino pelo tráfico de drogas, ainda que tal posição seja - ao que se colheu - bem evidente, outras razões como ascensão ao poder ou a ocupação de um lugar de destaque (Cortina, 2015). Os dados colhidos no decorrer da pesquisa aqui apresentada, bem como o relatório do Departamento Penitenciário Nacional demonstram essa relação, seja pelas informações a respeito das rendas médias familiares, seja pelos motivos declarados para o cometimento do crime.

Os relatos das entrevistadas sobre as circunstâncias em que a prisão ocorrera elucidam tal questão, além de colocar em evidência a instrumentalização dos corpos dessas mulheres para a realização de atividades ilícitas, inclusive por pessoas que com elas mantêm ou estabelecem relações, além da intervenção instrumentalizada dos "comandos".

Diversas mulheres relataram que foram surpreendidas pela polícia em sua residência, contam que a polícia invadiu e quase em nenhuma hipótese havia mandado de prisão ou busca e apreensão - somente em três casos as mulheres relataram que havia mandado de prisão -; fato que demonstra que já era de conhecimento das autoridades públicas o "ponto" de venda ou de armazenamento.

Mas o que é surpreendente é que as mulheres grávidas que foram presas na rodoviária (já dentro do ônibus) ou aguardando-o haviam feito um contato prévio e recente com seus próprios companheiros (presos e, portanto, com celular dentro de unidades prisionais) sendo em seguida surpreendidas pela polícia. Não foi possível apurar se os próprios companheiros usaram-nas como isca ou se estavam sendo monitoradas por escuta telefônica.

No entanto, algumas das mulheres relataram que foram abordadas na entrada do Complexo Penitenciário por uma mulher que lhes ofereceu uma quantia em dinheiro para adentrarem nas unidades prisionais portando substância entorpecente e que "já estava tudo acertado" com os agentes para liberar. Algumas citaram que o valor era de $\mathrm{R} \$ 600,00$; outra indicou que seriam $\mathrm{R} \$ 1.000,00$. A colocação da droga no corpo seria feita num banheiro feminino que fica no local de espera para o ingresso no Complexo.

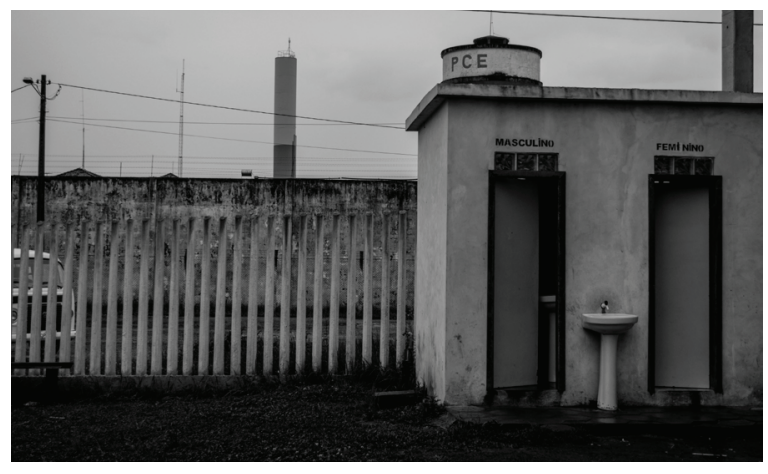

Entrada do Complexo Penitenciário de Piraquara. Fotografia por Valéria Kotacho Lopes 
Uma dessas mulheres, que diz ter sido assediada e aceitou a proposta, adentrou na unidade prisional com aproximadamente 380 gramas, relativos a 3 tipos de substâncias distintos, em seu corpo, mas foi pega pelo forte cheiro que uma das substâncias exalava. Algum tempo depois, o companheiro (que também era preso e estava na tal unidade faccionada) tinha-a deixado com o bebê já nascido e estava agora com outra mulher grávida que o visitava na prisão.

Outra mulher contou que estava grávida e perdeu o emprego que tinha num cemitério (temos inclusive a carta que ela escreveu para a juíza do seu processo) e que foi procurada por um vizinho para levar drogas na Delegacia de sua cidade, mas que quando lá chegou ficou tão nervosa que, segundo afirmou, "eu mesma me entreguei para o Delegado". Conta, ainda, que era sua segunda prisão, porque na primeira teve de "pagar uma dívida" de drogas de seu pai senão ele seria morto.

Os relatos das mulheres grávidas, associados aos das mulheres que visitam pessoas privadas de liberdade, sobre o poder dos "comandos" em gerir as filas, o sistema de visitas e o de revistas pode indicar que haja, de fato, essa comercialização dos corpos femininos.

\section{Possíveis conclusões: vale quanto pesa!}

O aumento da população carcerária masculina, não raro, pelas cifras elevadas - mais de 607.000 , segundo o último censo oficial (Brasil, 2015b), com as decorrências absolutamente degradantes propiciadas tanto pelo hiperencarceramento quanto pela falta de investimento em itens mínimos - nublam a questão das mulheres privadas de liberdade que em tal ocasião não superavam 36.000. Menos ainda, ganha destaque, com as ressalvas de trabalhos recentes, a questão das que foram presas grávidas e em que condições tais prisões foram realizadas. Talvez, em especial, pelo julgamento moral que se faça sobre uma mulher criminosa que esteja gestante ou seja mãe (Sá, 2014). Nesse recorte, bem específico, a questão em destaque, de regra, são as condições da gravidez e da maternagem no cárcere.

Olhar, no entanto, para as condições e as circunstân- cias em que tais prisões são realizadas, bem como a cifra de casos, em que mulheres grávidas são presas, fato que cada vez mais se evidencia, permite refletir sobre as permanências que o padrão heteronormativo e patriarcal, bem como o fato de que desenham, de forma binária, duas questões.

A primeira é a decorrência da divisão sexual do trabaIho, que se espraia no âmbito do trabalho ilícito, dado que o perfil socioeconômico das mulheres privadas de liberdade, grávidas e mães, parece confirmar a ocupação de postos subalternos no comércio de drogas, tal e qual no trabalho formal ou autônomo, ainda que não ilícito. A oferta de valores, denúncias anônimas e o uso de aparelhos celulares dentro das unidades, segundo o que relataram, além de não terem acesso a armas de fogo e lidarem com pequenas quantias em dinheiro, apresenta a feminização da pobreza que se evidencia, também, no mercado de drogas.

A segunda é a comercialização de seus próprios corpos, em estado de gravidez como véu para o encobrimento de práticas ilegais, tido também como mercadoria, por vezes, menos valiosa do que as próprias drogas que carregam. As práticas do comércio de drogas relacionadas tanto com componentes afetivos, quanto com econômicos parecem autorizar a afirmação de que seus corpos, como se fez muitas vezes na história oficial, da qual as mulheres não participaram nem como protagonistas, nem como narradoras, segue funcionando como objeto e como mercadoria, como meio e como fim.

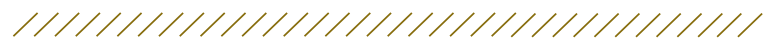




\section{Referências}

Andrade, V. R. P. de (2012). Pelas mãos da criminologia: o controle penal para além da (des)ilusão. Rio de Janeiro: Revan.

Brasil. Ministério da Justiça. Departamento Penitenciário Nacional (2015a). Levantamento nacional de informações penitenciárias: INFOPEN Mulheresjunho de 2014. Disponível em <http://justica.gov. $\mathrm{br} /$ noticias/estudo-traca-perfil-da-populacao-penitenciaria-feminina-no-brasil/relatorio-mulheres_05-11.pdf>. Acesso em 06 nov. 2015

Brasil. Ministério da Justiça. Departamento Penitenciário Nacional (2015b). Levantamento nacional de informações penitenciárias: INFOPEN - junho de 2014. Disponível em <http://www.justica.gov.br/noticias/ mj-divulgara-novo-relatorio-do-infopen-nesta-terca-feira/relatorio-depen-versao-web.pdf>. Acesso em 27 set. 2016

Brasil. Ministério do Planejamento, Orçamento e Gestão. Instituto Brasileiro de Geografia e Estatística (2015c). Síntese de Indicadores sociais: uma análise das condições de vida da população brasileira. Disponível em: <http://biblioteca.ibge.gov.br/visualizacao/livros/ liv95011.pdf >. Acesso em 20 set. 2016.

Brasil. Ministério da Justiça. (2014). Dar à luz nas sombras: condições atuais e possibilidades futuras para o exercício da maternidade por mulheres em situação de prisão. Série pensando o Direito. N. 51. Disponível em <http://www.justica.gov.br/noticias/201clugar-de-crianca-nao-e-na-prisao-nem-longe-de-sua-mae201d-diz-pesquisa/pesquisa-dar-a-luz-na-sombra-1.pdf>. Acesso em: 27 set. 2016.

Birolli, F. (2013). Autonomia e desigualdades de gênero: contribuições do feminismo para a crítica democrática. Vinhedo: Editora Horizonte.

Castro, A. M. A.; Egger, E. (2012). Alguns apontamentos sobre a epistemologia feminista. Revista Sociais e Humanas. v. 25, n. 2, 231-238. Disponível em: <https://periodicos.ufsm.br/sociaisehumanas/article/view/2862>. Acesso em: 20 set. 2016.

Cortina, M. O. de C. (2015). Mulheres e tráfico de drogas: aprisionamento e criminologia feminista. Revista de estudos feministas. Disponível em $<$ https://periodicos.ufsc.br/index.php/ref/article/ view/41765/30378>. Acesso em: 27 set. 2016.

Departamento Penitenciário do Paraná - DEPEN-PR. (s.d.). Estabelecimentos penais. Disponível em: $<$ http://www.depen.pr.gov.br/>. Acesso em: 23 out. 2017.

Diniz, D. (2014). Cadeia. Rio de Janeiro: Civilização Brasileira.

Espinoza, O (2004). A Mulher Encarcerada em Face do Poder Punitivo. São Paulo: IBCCRIM.

Heretiér, F. (2015). Masculino e Feminino I: o pensamento da diferença. Lisboa: Instituto Piaget.

Hespanha, A. M. (2010). Imbecillitas: As bem-aventuranças da inferioridade nas sociedades de Antigo Regime. São Paulo: Annablume.

Lucas, L.; Hoff, T. (2008). Formas sutis de dominação hierarquizada: Corpo e feminização da pobreza. Exaequo, Vila Franca de Xira, n. 17. Disponível em: $<$ http://www.scielo.mec.pt/scielo.php?script=sci_ arttext\&pid=S0874-55602008000100009\&lng=pt\&nr m=iso>. Acesso em: 19 set. 2016

Matos, M. (2008). Teorias de gênero ou teorias e gênero? Se e como os estudos de gênero e feministas se transformaram em um campo novo para as ciências. Revista Estudos Feministas, 16(2), 333-357. Disponível em: <https://dx.doi.org/10.1590/S0104-026X2008000200003>. Acesso em: 20 set. 2016.

Macedo, M. S. (2008). Mulheres chefes de família e a perspectiva de gênero: trajetória de um tema e a crítica sobre a feminização da pobreza. Caderno CRH, 21(53), 385-399. Disponível em <https:// dx.doi.org/10.1590/S0103-49792008000200013>. Acesso em: 20 set. 2016.

Mendes, S. da R. (2014). Criminologia feminista: novos paradigmas. São Paulo: Saraiva.

Paraná. Departamento Penitenciário do Estado do Paraná. Disponível em: http://www.depen.pr.gov. br. Acesso em 25 jul. 2016.

Perrot, M. (1988). Os excluídos da história: operários, mulheres e prisioneiros. Trad. Denise Bottmann. Rio de Janeiro: Paz e Terra.

Queiroz, N. (2014). Presos que menstruam. Rio de Janeiro: Record.

Sá, P. P. (2015). O sistema penal e suas inimigas: o controle dos corpos femininos de presas comunistas e traficantes. Boletim IBCCRIM. Ano 23. n. 274. Disponível em: <http://www.ibccrim.org.br/ site/boletim/pdfs/Boletim274.pdf>. Acesso em: 27 set. 2016.

Data de submissão/Submission date: 29.09.2016.

Data de aceitação para publicação/Acceptance date: 29.05.2017. 